\title{
Effect of Contraceptive use on Menstrual Cycle Pattern among clients attending Family Planning Clinics at Assiut City
}

\author{
Nagah Farhan Mohammed, Mahmoud Ahmed Mahmoud Abdel-Aleem \& Ghadah Abdelrahman Mahmoud. \\ Nursing specialist, Ministry of Health, Assiut Governorate, Egypt. \\ Professor of Obstetrics \& Gynecology Faculty of Medicine, Assiut University, Egypt. \\ Assistant Professor of Obstetrics \& Gynecological Nursing, Faculty of Nursing, Assiut University, Egypt.
}

\begin{abstract}
Services of Family planning have an essential role for improving the quality of family's lives and also their economic welfare. Family planning methods may lead to menstrual changes such as menorrhagia, oligomenorrhea or inter-menstrual spotting. Aim of the study: to assess the effect of contraceptive use on menstrual cycle patterns among clients attending family planning clinics in Assiut City and to assess the effect of menstrual cycle side effects on contraceptive discontinuation among these clients. Subject and Methods: This prospective study was conducted on1570 clients in F.P. clinics serve the west sector of Assiut city by using a structured interviewing and follow up questionnaires. Results: There are statistical significant differences between case \&control group as regards Monthly Injectable, the combined pills and Progestin-Only Injectable used and menstrual disorders respectively. There is statistical significant difference between different method of family planning methods and discontinuation rate $(\mathrm{P} . \mathrm{V}=0.008)$ and between contraceptive methods and its side effects at the first and second follow up (P.V= $<0.001$ and 0.001) respectively. Conclusions: Contraceptive use significantly affects the menstrual cycle and discontinuation rate of its users. Recommendations: Contraceptive counseling must be included knowledge about menstrual pattern changes. More researches should be done to assess the impact of family planning counseling on reducing the rate of unwanted pregnancy.
\end{abstract}

\section{Key Words: Family Planning, Menstrual changes and Discontinuation.}

\section{Introduction}

Family planning (FP) is an effective factor for reducing child and maternal mortality. The role of family planning as an international strategy for safe motherhood and child survival is remarkable. There are more than 100 million women in developing countries, $17 \%$ of all married women, would prefer to avoid pregnancy, but without using any form of FP. Unmet need for contraception can lead to unintended pregnancies, i.e. unwanted pregnancy can raise maternal, familial, and social risks. About $25 \%$ of pregnancies in developing countries are unintended (El-Zanaty, 2008).

According to the Population Reference Bureau's Family Planning Worldwide 2008 Data Sheet, female sterilization is the most public method used by about one-fifth of the married women of reproductive age. Intrauterine devices (IUDs), pills, condoms, indictable, male sterilization, and several traditional methods are the followed methods respectively. Other recent methods: such as hormonal implants, diaphragms and spermicidal represent as a very small percentage of them (FPWDS, 2008).

Current contraceptive use reported by EDHS, 2014 explored that $59 \%$ of Egyptian married women in are using a contraceptive method. The most public method is IUD $30 \%$, then the pill $16 \%$ and injectable $9 \%$ respectively. There are significant differences at the level of family planning use by residence. Women lived in urban areas $(61 \%)$ are more using than women lived in rural areas $(57 \%)$ (EDHS, 2014).

There are different types of Family planning methods such as: Hormonal oral contraceptives "pills, injectable; sub dermal implants"; mechanical method "intrauterine devices (IUDs)"; surgical method "female and male sterilization; and barrier methods such as male and female condoms, diaphragms and spermicidal. Other recent methods include: Lactation Amenorrhea Method (LAM)\& fertility awareness methods (Johns, et al., 2012).

In Egypt every 23.5 seconds; there is a baby born. It means an increase of 3680 people every day. The dramatic increasing in population rose from 64.6 million people in 2001 to 78.7 million in 2008 . According to EDHS, 2008, the total fertility rate is 3.1 children. Woman unplanned births reached $17 \%$ and unmet need for family planning is $10 \%$

(El-Zanaty, 2008).

According to EDHS, 2014; the total population in Egypt is about 82.541 million in 2012, while Assuit governorate which is one of the middle populated governorate with a number of population about 3.953 million. It represents $5 \%$ of total population in Egypt (EL-Zanaty, 2014). 
Contraceptives methods have numerous side effects especially hormonal methods. These side effects include: breast tenderness ,menstrual disorders, abdominal cramps, nausea, acne, headaches dizziness, reduced libido and mood changes (WHO, 2007).

The variations of menstrual changes based on some factors as: clients, methods and duration of use. These factors require good counseling for these contraceptive clients. For example, IUDs may increase menstrual bleeding and cramping In contrast, the implant and the injectable can lead to slight bleeding or temporary amenorrhea. (Stacey, et al., 2012).

Egypt Demographic Health Survey report 2014 , discontinuation rate of family planning use represents $30 \%$ within 12 one year of starting use (EDHS, 2014B).

The main cause of family planning discontinuation and the occurrence of unintended pregnancy are changing in bleeding patterns. So the good counselor should focus on this topic during client's session. (NHS, 2010).

Many factors can affect contraceptive discontinuation such as: women's socioeconomic status including: education, occupation and the family's income. Other factors as: the wrong knowledge about family planning method, the women's autonomy (Sakar, 2008).

The main reasons for discontinuing use of contraceptive method are: a desire to get pregnant, method failure of use, desire for a another family planning method, side effects, and health concerns reasons for contraceptive discontinuation have changed in these years, with more women stopping contraceptive use due to get pregnant or the bad experience of its side effects (USAID,2007).

\section{Aims of the Study were to}

- Assess the effect of contraceptive use on menstrual cycle pattern among clients attending family planning clinics in Assiut City.

- Assess the effect of menstrual cycle side effects on contraceptive discontinuation among these clients.

Research questions

- What is the relation between contraceptive use and menstrual cycle pattern?

- What is the relation between contraceptive side effects and its discontinuation?

\section{Subject and Methods}

Research design: Descriptive research design was utilized in this study.

Setting of study

This prospective study was applied at F.P. clinics which serves the west sector of Assiut city. This sector includes. Kolta $\mathrm{MCH}$, Hay Gharb $\mathrm{MCH}$
,Elarbaeen MCH and Assiut General Hospital. These clinics provide family planning services for about 15481 clients during 2012 Kolta $\mathrm{MCH}$ received (990 Client's), Hay Gharb $\mathrm{MCH}$ received (6536 Client's),Elarbaeen $\mathrm{MCH}$ received (6116 Client's) and Assiut General Hospital received ( 3166 Client's) respectively.

\section{Sample}

Purposive sample of all Clients attending Family Planning Clinics in Assiut City during the period of data collection were evaluated for eligibility .their total number was 1570 women with the following criteria:

\section{Inclusion criteria}

- All women in reproductive age from 15 -45 years and used contraceptive methods

- Women who will agree to participate in the study

Exclusion criteria

- Pregnant women at the time of study

- Old age women more than 45years

- History of menstrual disorder

- Blood disease

Sample size

The sample was calculated by using Epi-Info statistical package, version 3.3 with power $80 \%$ value of 2.5 is chosen as the acceptable limit of precision (D) at $95 \%$ level of confidence (CI), with expected prevalence $50 \%$ and worst acceptable $60 \%$. Accordingly, sample size is estimated to be $1550+10 \%$ individuals to guard against nondespondence rate. The computed sample size plus expected dropout rate was 1570 prospective women. 


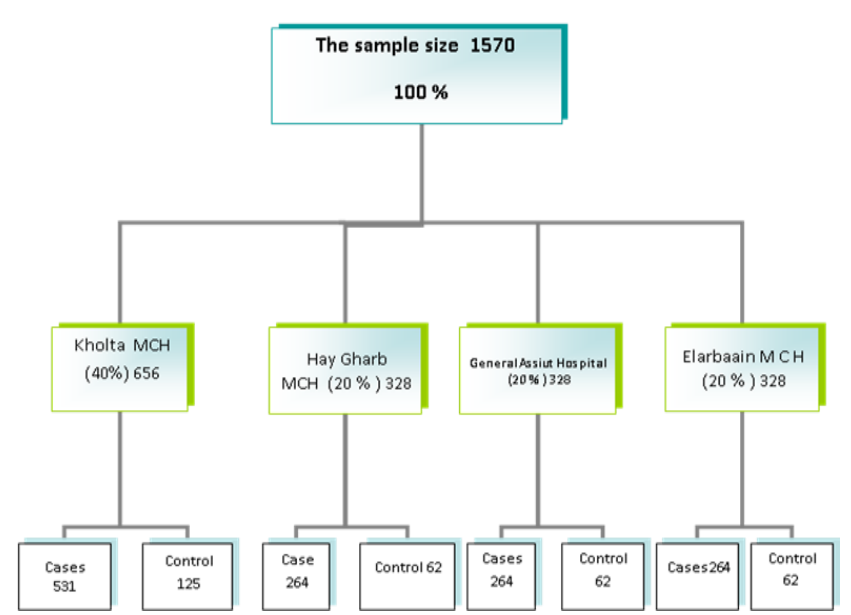

The distribution of the sample size will be as the following:

\section{Data collection tools:}

The tools used for data collection consisted of structured interviewing questionnaire and follow- up sheet:

I. A structured interviewing questionnaire was designed and developed by the researcher after reviewing different related researches, pertinent literature, and revision from three experts in Obstetrics and Gynecology professors in Nursing and Medical science at Assiut University. According to the opinions of experts necessary modifications were done to ensure validity and reliability to collect the following data:

Part 1: Socio demographic data :(Name, age, occupation, address, telephone number, education Level, residence, date of admission and duration of marriage ).

Part 2: Menstrual History :( Age at menarche, duration of menstrual blood flow, menstrual rhythm, amount of menstruation and menstrual disorder).

Part 3: Obstetric History :( Number of Gravidity, parity, Living children, Abortion, normal vaginal deliveries and Cesarean section) .

Part 4: Medical History :( Diabetes mellitus, hypertension, Heart disease, Epilepsy, lever diseases, varicose veins and history of breast tumors)

Part 5: Family planning :( The type of contraceptive methods used, duration of use /month and the causes of discontinuation of contraceptive methods (Side effects of menstruation, to get pregnant, desire of her husband, other side effects of the method, travel of her husband and others).

Part 6: Data related to present F.P use: type of contraception used such as ; ( Hormonal contraceptive pills, IUD, injectabl, implanon, natural methods and others). Duration of use, side effects, menstrual disorders and discontinuation

\section{II-Follow up sheet:}

The investigator interviewed the Client again at the Clinics for two times. The $1^{\text {st }}$ time after one month to ask the client about the F.P method still continued or not? Presence of any side effects (Yes/No), The method correctly used and consistently, Discontinuation (Yes/No), Causes of discontinuations. Then the investigator gave the client information about family planning issues through health education's session.

At the $2^{\text {nd }}$ time, the client came again after 2 months and the researcher repeat the same questions to the Client.

\section{Operational design}

This design involved description of the preparatory phase, the pilot study and filed work.

\section{Preparatory phase}

The researcher reviewed related literature local \&international using textbooks, web articles and scientific magazines. The tools were designed. Validity

The tools were reviewed for validity by 3 experts in Obstetrics and Gynecology to test validity and reliability of the research, necessary modification were done.

\section{Pilot study}

Pilot study was conducted on the $10 \%$ of the study sample during the first two week to test the clarity of the questions and to detect any further problems or difficulties that help in making the necessary modification in the questionnaire that was reconstructed. The pilot study was excluded from the total sample.

\section{Ethical consideration}

The purpose of this study was explained to all women. The women have ethical rights to agree or refuse to participate in the study; oral consent was taken from all women who were participated to the study and informed that the information and data obtained will be confidential and used only for the purpose of the study.

\section{Field work}

- The study was carried out during the period from first of June 2013 and ended in January 2014.

Methods: An official permission was obtained from pertinent authorities. The researcher introduced herself to the eligible woman, greeted client and then obtained informed consent of woman (verbal) to participate in the research after full explanation of the nature of the research. Two days per week were specified for data collection. The researcher attended $\mathrm{MCH}$ to meet clients.

- The investigator interviewed the women face to face; each interview took 15 minutes with each woman. The investigator recorded Sociodemographic, Obstetric history, Medical history, 
F.P history, Present F.P data. During the interview determination of the Client $\mathrm{s}$ knowledge about sources of information regarding family planning methods, the type of previous contraceptive method used and the reasons of discontinuation if present (To get pregnant, desire of her husband, Side effects of the method, Travel of her husband and others).

- The investigator asks the Client's about any side effects of method used, focusing on menstrual disorders.

- The investigators provided health education about family planning methods (Method of administration, advantages, disadvantages, side effects, efficacy, suitable birth spacing, and factors to consider when selecting a birth control method and benefits of F.P) and the client supplied with a follow-up card indicating the date of next visit. The card also includes general information about F.P and the phone numbers of the researcher to answer any urgent questions. The woman was asked to leave her contact phone number in case she was unable to attend her follow-up visit to complete the missed data.

\section{Follow up}

The same client in the study was met again by the researcher for two times, the $1^{\text {st }}$ time after one month from the time of enrolment and the $2^{\text {nd }}$ time, after another 2 months to complete the required data. Those who did not attend the clinic were contacted by phone. The investigator interviewed the client to ask her about The F.P method still continued or not?, Presence of any side effects, The method correctly used and consistently, discontinuation and its causes if present The investigator was sure that the client understood F.P; discovered how much she can recall correctly, Identify her acceptance and misunderstanding knowledge about F.P.

At the $2^{\text {nd }}$ time, the client came again after 2 months and asked her the same questions. Through the process of collection of data, the investigator took cases as a control group (the group enrolled from outpatient clinic of Gynecology, these women at reproductive age, didn't use F.P.) to exclude the other causes for menstrual disorders rather than contraceptive methods.

\section{Administrative design}

An official permission will be obtained from the Dean of the faculty to manager of the Directorate of F.P clinics - Ministry of Health; the investigator will explain the nature and the aims of the study.

Oral consent of the participant will be obtained

\section{Statistical design}

Categorical variables were described by number and percent $(\mathrm{N}, \%)$, where continuous variables described by mean and standard deviation (Mean, SD). Chi- square test used to compare between categorical variables where compare between continuous variables by independent t-test. A two-tailed $\mathrm{p}<0.05$ was considered statistically significant. All analyses were performed with the SPSS 20.0 software. 


\section{Results}

Table (1): Distribution of women regarding to Socio demographic characteristics $(n=1570)$.

\begin{tabular}{|c|c|c|}
\hline \multirow{2}{*}{ Socio demographic characteristics } & \multicolumn{2}{|c|}{ Total (1570) } \\
\hline & No. & $\%$ \\
\hline \multicolumn{3}{|l|}{ Women age } \\
\hline 30 and less years & 989 & 62.9 \\
\hline$>30-40$ years & 442 & 28.2 \\
\hline$>40$ years & 139 & 8.9 \\
\hline Total & 1570 & 100 \\
\hline Range & \multicolumn{2}{|c|}{$\frac{1}{17->40}$} \\
\hline Mean+SD & \multicolumn{2}{|c|}{$29.6 \pm 7.2$} \\
\hline \multicolumn{3}{|l|}{ Residence } \\
\hline Rural & 427 & 27.2 \\
\hline Urban & 1143 & 72.8 \\
\hline Total & 1570 & 100 \\
\hline \multicolumn{3}{|l|}{ Level of education } \\
\hline Higher education & 302 & 19.2 \\
\hline Secondary & 658 & 41.9 \\
\hline Basic education & 121 & 7.7 \\
\hline Read and write & 111 & 7.1 \\
\hline Illiterate & 378 & 24.1 \\
\hline Total & 1570 & 100.0 \\
\hline \multicolumn{3}{|l|}{ Occupation } \\
\hline House wife & 1317 & 83.9 \\
\hline Employee & 253 & 16.1 \\
\hline Total & 1570 & 100 \\
\hline Range & \multicolumn{2}{|c|}{$20-68$} \\
\hline Mean+SD & \multicolumn{2}{|c|}{$35.6 \pm 7.5$} \\
\hline \multicolumn{3}{|l|}{ Duration of marriage } \\
\hline $1-10$ years & 1025 & 65.3 \\
\hline $10-20$ years & 404 & 25.7 \\
\hline $20-30$ years & 133 & 8.2 \\
\hline$>30 \pm$ years & 8 & 0.5 \\
\hline Total & 1570 & 100 \\
\hline
\end{tabular}

Table (2): The relationship between menstrual disorders in progestogen-only users and non contraceptives users

\begin{tabular}{|l|c|c|c|c|c|}
\hline \multirow{2}{*}{ Menstrual disorders } & \multicolumn{2}{|c|}{$\begin{array}{c}\text { The progestogen-onl } \\
\text { (“mini”) pill (n=216) }\end{array}$} & \multicolumn{2}{|c|}{ Control (n=311) } & \multirow{2}{*}{ P. value } \\
\cline { 2 - 5 } & No. & $\mathbf{\%}$ & No. & \% & \\
\hline Amenorrhea & 2 & 0.9 & 6 & 1.9 & 0.572 \\
\hline Inter menstrual bleeding & 0 & 0.0 & 0 & 0.0 & - \\
\hline Inter menstrual spotting & 4 & 1.9 & 1 & 0.3 & 0.185 \\
\hline Dysmenorrheal & 0 & 0.0 & 2 & 0.6 & 0.645 \\
\hline
\end{tabular}


Table (3): The relationship between menstrual disorders in Monthly Injectable users and non-contraceptives users.

\begin{tabular}{|c|c|c|c|c|c|}
\hline \multirow{2}{*}{ Menstrual disorders } & \multicolumn{2}{|c|}{$\begin{array}{l}\text { Monthly Injectable } \\
(\mathbf{n}=\mathbf{3 3})\end{array}$} & \multicolumn{2}{|c|}{ Control $(n=311)$} & \multirow{2}{*}{ P. value } \\
\hline & No. & $\%$ & No. & $\%$ & \\
\hline Amenorrhea & 3 & 9.1 & 6 & 1.9 & 0.060 \\
\hline Inter menstrual bleeding & 1 & 3.0 & 0 & 0.0 & 0.169 \\
\hline Inter menstrual spotting & 3 & 9.1 & 1 & 0.3 & $0.001 * *$ \\
\hline Dysmenorrheal & 0 & 0.0 & 2 & 0.6 & 0.458 \\
\hline
\end{tabular}

Table (4): The relationship between menstrual disorders in the combined pills and non contraceptives users

\begin{tabular}{|l|c|c|c|c|c|}
\hline \multirow{2}{*}{ Menstrual disorders } & \multicolumn{2}{|c|}{$\begin{array}{c}\text { The combined pill } \\
(\mathbf{n = 2 0 0})\end{array}$} & \multicolumn{2}{|c|}{ Control (n=311) } & \multirow{2}{*}{ P. value } \\
\cline { 2 - 6 } & No. & $\mathbf{\%}$ & No. & \% & \\
\hline Amenorrhea & 3 & 1.5 & 6 & 1.9 & 0.978 \\
\hline Inter menstrual bleeding & 8 & 4.0 & 0 & 0.0 & $0.001 * *$ \\
\hline Inter menstrual spotting & 2 & 1.0 & 1 & 0.3 & 0.699 \\
\hline Dysmenorrheal & 0 & 0.0 & 2 & 0.6 & 0.681 \\
\hline
\end{tabular}

Table (5): The relationship between menstrual disorders in Progestin-Only Injectables users and noncontraceptives users

\begin{tabular}{|c|c|c|c|c|c|}
\hline \multirow[t]{2}{*}{ Menstrual disorders } & \multicolumn{2}{|c|}{$\begin{array}{r}\text { Progestin- -Only } \\
\text { Injectables }(n=206)\end{array}$} & \multicolumn{2}{|c|}{ Control $(n=311)$} & \multirow[t]{2}{*}{ P. value } \\
\hline & No. & $\%$ & No. & $\%$ & \\
\hline Amenorrhea & 54 & 26.2 & 6 & 1.9 & $<0.001 * *$ \\
\hline Inter menstrual bleeding & 7 & 3.4 & 0 & 0.0 & $0.004 * *$ \\
\hline Inter menstrual spotting & 1 & 0.5 & 1 & 0.3 & 0.667 \\
\hline Dysmenorrheal & 0 & 0.0 & 2 & 0.6 & 0.667 \\
\hline
\end{tabular}

Table (6): The relationship between menstrual patterns in IUDs users and non-contraceptives users.

\begin{tabular}{|l|c|c|c|c|c|}
\hline \multirow{2}{*}{ Menstrual disorders } & \multicolumn{2}{|c|}{ IUDs (n=352) } & \multicolumn{2}{|c|}{ Control (n=311) } & \multirow{2}{*}{ P. value } \\
\cline { 2 - 5 } & No. & $\mathbf{\%}$ & No. & \% & \\
\hline Amenorrhea & 2 & 0.6 & 6 & 1.9 & 0.212 \\
\hline Inter menstrual bleeding & 6 & 1.7 & 0 & 0.0 & 0.057 \\
\hline Inter menstrual spotting & 3 & 0.9 & 1 & 0.3 & 0.705 \\
\hline Dysmenorrheal & 1 & 0.3 & 2 & 0.6 & 0.914 \\
\hline
\end{tabular}

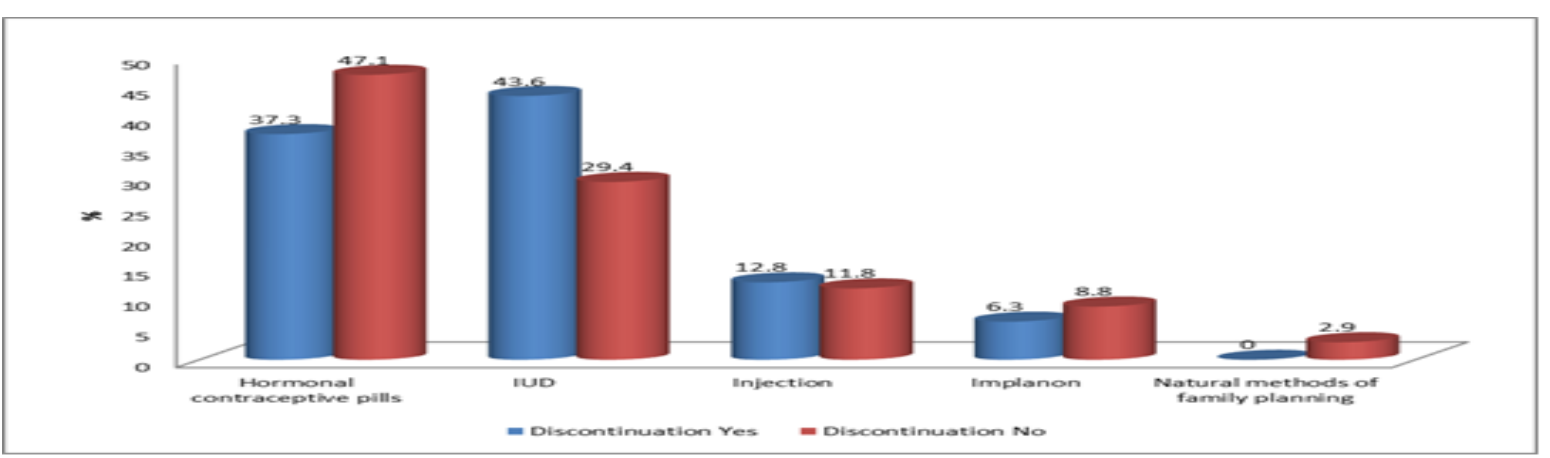

Figure (1): Relation between History of contraceptive methods and discontinuation 
Table (7): The relationship between History F.P methods and causes of discontinuation causes ( $n=447)$

\begin{tabular}{|c|c|c|c|c|c|c|c|c|c|c|c|}
\hline & \multicolumn{2}{|c|}{$\begin{array}{c}\text { Hormonal } \\
\text { contraceptiv } \\
\text { e pills } \\
\end{array}$} & \multicolumn{2}{|c|}{ IUD } & \multicolumn{2}{|c|}{ Injection } & \multicolumn{2}{|c|}{ Implanon } & \multicolumn{2}{|c|}{ Others } & \multirow[t]{2}{*}{ P. value } \\
\hline & No & $\%$ & No & $\%$ & No & $\%$ & No & $\%$ & No & $\%$ & \\
\hline To get pregnant & 15 & 9.8 & 5 & 2.8 & 0 & 0.0 & 0 & 0.0 & 0 & 0.0 & \multirow{5}{*}{$<0.001 * *$} \\
\hline $\begin{array}{l}\text { desire of her } \\
\text { husband }\end{array}$ & 87 & 56.9 & 113 & 62.8 & 25 & 47.2 & 9 & 34.6 & 1 & 100.0 & \\
\hline $\begin{array}{l}\text { Side effects of the } \\
\text { method }\end{array}$ & 39 & 25.5 & 39 & 21.7 & 15 & 28.3 & 1 & 3.8 & 0 & 0.0 & \\
\hline $\begin{array}{l}\text { Travel of her } \\
\text { husband }\end{array}$ & 4 & 2.6 & 2 & 1.1 & 6 & 11.3 & 1 & 3.8 & 0 & 0.0 & \\
\hline Others & 8 & 5.2 & 21 & 11.7 & 7 & 13.2 & 15 & 57.7 & 0 & 0.0 & \\
\hline Total & 153 & 100 & 180 & 100 & 53 & 100 & 26 & 100 & 1 & 100.0 & \\
\hline
\end{tabular}

Table (8): The relationship between contraceptive methods and discontinuation in first follow up\& second follow up.

\begin{tabular}{|c|c|c|c|c|c|c|c|c|c|c|}
\hline \multirow{3}{*}{ Current method } & \multicolumn{4}{|c|}{$\begin{array}{l}\text { The family planning method } \\
\text { is still continued first follow up }\end{array}$} & \multirow{3}{*}{$\begin{array}{c}P . \\
\text { value }\end{array}$} & \multicolumn{4}{|c|}{$\begin{array}{l}\text { The family planning method is } \\
\text { still continued second follow up }\end{array}$} & \multirow{3}{*}{ P. value } \\
\hline & \multicolumn{2}{|c|}{ Yes } & \multicolumn{2}{|c|}{ No } & & & es & & & \\
\hline & No & $\%$ & No & $\%$ & & No. & $\%$ & No & $\%$ & \\
\hline $\begin{array}{l}\text { progestogen-only } \\
\text { ("mini") pill }\end{array}$ & 105 & 97.2 & 3 & 2.8 & \multirow{7}{*}{0.081} & 98 & 93.3 & 7 & 6.7 & \multirow{7}{*}{$0.008 * *$} \\
\hline $\begin{array}{l}\text { The combined } \\
\text { pill }\end{array}$ & 53 & 98.1 & 1 & 1.9 & & 44 & 83.0 & 9 & 17.0 & \\
\hline $\begin{array}{l}\text { Progestin- -Only } \\
\text { injectable }\end{array}$ & 51 & 100.0 & 0 & 0.0 & & 48 & 94.1 & 3 & 5.9 & \\
\hline $\begin{array}{l}\text { Monthly } \\
\text { Injectable }\end{array}$ & 20 & 87.0 & 3 & 13.0 & & 18 & 90.0 & 2 & 10.0 & \\
\hline The Implant & 15 & 100.0 & 0 & 0.0 & & 15 & 100.0 & 0 & 0.0 & \\
\hline IUDs & 141 & 94.6 & 8 & 5.4 & & 138 & 97.9 & 3 & 2.1 & \\
\hline Male condom & 15 & 100.0 & 0 & 0.0 & & 14 & 93.3 & 1 & 6.7 & \\
\hline Total & 400 & 96.4 & 15 & 3.6 & & 375 & 93.8 & 25 & 6.3 & \\
\hline
\end{tabular}


Table (9): The relationship between types of contraceptives methods and its side effect in the first and second follow up

\begin{tabular}{|c|c|c|c|c|c|c|c|c|c|c|c|}
\hline \multirow{2}{*}{ Current method } & \multicolumn{2}{|c|}{ Back pain } & \multicolumn{2}{|c|}{$\begin{array}{c}\text { Vaginal } \\
\text { infections }\end{array}$} & \multicolumn{2}{|c|}{$\begin{array}{c}\text { pain in lower } \\
\text { abdomen }\end{array}$} & \multicolumn{2}{|c|}{$\begin{array}{c}\text { Nausea, } \\
\text { Vomiting }\end{array}$} & \multicolumn{2}{|c|}{$\begin{array}{l}\text { More than } \\
\text { symptoms }\end{array}$} & \multirow{2}{*}{ P. value } \\
\hline & No & $\%$ & No & $\%$ & No & $\%$ & No & $\%$ & No & $\%$ & \\
\hline \multicolumn{12}{|c|}{ First month of follow up } \\
\hline $\begin{array}{l}\text { progestogen-only } \\
\text { (“mini”) pill } \\
\end{array}$ & 5 & 13.5 & 0 & 0.0 & 0 & 0.0 & 6 & 25.0 & 2 & 40.0 & \multirow{6}{*}{$<0.001 * *$} \\
\hline The combined pill & 0 & 0.0 & 0 & 0.0 & 1 & 7.1 & 3 & 12.5 & 0 & 0.0 & \\
\hline $\begin{array}{l}\text { Progestin- -Only } \\
\text { injectable }\end{array}$ & $\begin{array}{c}1 \\
5\end{array}$ & 40.5 & 0 & 0.0 & 3 & 21.4 & $\begin{array}{l}1 \\
0\end{array}$ & 41.7 & 0 & 0.0 & \\
\hline Monthly Injectable & 4 & 10.8 & 0 & 0.0 & 2 & 14.3 & 2 & 8.3 & 0 & 0.0 & \\
\hline The Implant & 0 & 0.0 & 0 & 0.0 & 1 & 7.1 & 2 & 8.3 & 0 & 0.0 & \\
\hline IUDs & 13 & 35.1 & 15 & 00.0 & 7 & 50.0 & 1 & 4.2 & 3 & 60.0 & \\
\hline \multicolumn{12}{|c|}{ Second month of follow up } \\
\hline $\begin{array}{l}\text { progestogen-only } \\
\text { ("mini") pill }\end{array}$ & 6 & 14.0 & 0 & 0.0 & 3 & 27.3 & 9 & 36.0 & 0 & 0.0 & \multirow{6}{*}{$0.001 * *$} \\
\hline The combined pill & 1 & 2.3 & 0 & 0.0 & 0 & 0.0 & 0 & 0.0 & 0 & 0.0 & \\
\hline $\begin{array}{l}\text { Progestin- -Only } \\
\text { injectable }\end{array}$ & $\begin{array}{l}1 \\
7 \\
\end{array}$ & 39.5 & 2 & 14.3 & 6 & 54.5 & 11 & 44.0 & 0 & 0.0 & \\
\hline Monthly Injectable & 1 & 2.3 & 0 & 0.0 & 0 & 0.0 & 3 & 12.0 & 0 & 0.0 & \\
\hline The Implant & 2 & 4.7 & 0 & 0.0 & 1 & 9.1 & 0 & 0.0 & 0 & 0.0 & \\
\hline IUDs & 16 & 37.2 & 12 & 85.7 & 1 & 9.1 & 2 & 8.0 & 4 & 100.0 & \\
\hline
\end{tabular}

Table (1): shows the socio-demographic characteristics of the studied women. The mean age of recruited women was $(29.6 \pm 7.2)$ years in studied women, more than half $(55.9 \%)$ of the them between the age of 20-30 years, while the level of education explores that more than two fifth $(41.9 \%)$ of women had secondary school, and it was observed that the majority of women were house wife's $(83.9 \%)$. As regards to residence, less than three quarters of the sample $(72.8 \%)$ were living in urban areas.

Table (2): shows that there is no statistical significant difference between progestogen-only ("mini") users as a case group and non-contraceptive users as a control group and Menstrual disorders (P.v > 0.05 )

Table (3): shows that there is a statistical significant difference between case \&control group with Monthly Injectable used by women and Inter menstrual spotting (p.v=0.001).

Table (4): shows that there is a statistical significant difference between case \&control group with the combined pills used by women and Inter menstrual bleeding ( $\mathrm{p} . \mathrm{v}=0.001)$.

Table (5): shows that there is a statistical significant difference between case control group with Progestin-Only Injectables used by women and Amenorrhea\& Inter menstrual bleeding (p.v= $<0.001 \& 0.004)$ respectively .
Table (6): shows that there is no a statistical significant difference between case \&control group with IUD used by women and menstrual disorders.

Table (7): shows that there is statically significant difference between causes of discontinuation and types of contraceptive methods ( $\mathrm{p} . \mathrm{v}=<0.001$ ).

Table (8): clears that there is statistical significant difference between contraceptive methods and discontinuation in first follow up\& second follow up (p.v=0.007).

Table (9): shows that there is statistical significant difference between contraceptive methods and its side efects in the first and second follow up (P.v= $<0.001$ and 0.001$)$ respectively.

Figure (1): shows that there is statistical significant difference between different method of family planning and discontinuation.

\section{Discussion}

Many factors can affect family planning use such as: customs and traditions, morals and mass media. The variations of acceptance and promotions of family planning methods depend on socioeconomic environment, especially economic and educational level (Ghosh, 2014).

The current study had two aims: the first was to assess the effect of contraceptive use on menstrual 
cycle pattern and to assess the effect of menstrual cycle side effects on contraceptive discontinuation among clients attending family planning clinics in Assiut City .

The present study explored that more than half of women aged 30 years or less. This finding was congruent with Lwelamira, et al., (2012) who mentioned that half of participant aged 30 years or less in Tanzania. At the same line, Elzanaty, 2008 who explored that more than half of women aged nearly the same age.

As regards contraceptive methods used by participants, the current findings illustrated that more than one third of women used contraceptive pills and IUDs respectively. Similar finding was reported by Subir, (2010) who revealed that IUDs was the commonly contraceptive methods used. At the opposite line with Lwelamira, et al., (2012) who noted that nearly three quarters of participants used contraceptive injectable followed by pills.

As regards side effect, the present study revealed that $(4 \%)$ of women have inter-menstrual bleeding with OCPs users. This finding disagreed with study carried out in the United States by Al-Rayyan et al., (2011) who reported that more than half of participants have breast discomfort.

Also, the present study shows that (1.7\%) used IUD has menstrual disorder (inter menstrual bleeding). Similar findings was found in the study carried out in Tabriz by Fardy et al., 2006 they found that the main cause of IUD discontinuation was irregular bleeding.

Similar findings were found in the study carried out in Nepal by Thapa, (2012) showed that the major side effects of IUD were bleeding, menstrual disorder, and abnormal vaginal discharge respectively. At the other line, it was disagreed about Causes of discontinuation of IUD. This finding was supported by Naser et al., (2009) who reported in their study that half of women used contraceptive injectable had amenorrhea.

The present study shows that one third of women used Depo-Provera have amenorrhea. This finding was adopted by Azar et al., (2006) \& also supported by Veisi, \& Zangeneh, (2013) who showed that the most important side effects in injectable group were menstrual cycle problems, like amenorrhea, weight gain, bone pains and vaginal dryness respectively. This result is supported by Azar and Zanghi, (2006) who noted that also one third of minipills complications were due to irregular bleeding.

The present study supported by Balogun \& Raji, (2009) who reported that menstrual irregularity was the commonest side effect of Progesterone Only Contraceptive (POC) and disagreed in causes of POC discontinuation.

The present study shows that $9.1 \%$ of side effect of Implanon were pain in lower abdomen in the first and second follow up, this result disagreed with Pushpa, et al., (2011) in the study carried out in India who reported that the commonest side effect was irregular bleeding, Prolonged spotting and complained of amenorrhea respectively.

The present study shows that the vast majority still continued family planning methods in the first and the second follow respectively. The present study supported by Adeyemi, et al., (2012) who reported that there is a good continuation rate of the contraceptive method, as more than three quarters of the women were still on the method after 12 months.

The present study shows that discontinuation was the highest among IUDs users followed by Hormonal contraceptive pills and then injectable. These findings were disagreed with the study done in Egypt by El- shereef et al., (2011) who mentioned that discontinuation was the highest among injectable followed by IUDs users, then OCPs.

The present study shows that more than half of women used IUD discontinue the contraceptive method as a result of desire of the husband. This result disagreed with El- shereef et al., (2011) who reported that as regards causes of discontinuations, side effects and health concerns were the most common reasons of discontinuation. The desire to become pregnant was also frequently mentioned for discontinuing use.

As regard to reasons of discontinuation, results revealed that more than half used IUD of the studied women discontinue the contraceptive method as a result of desire of the husband. This finding is similar to the results of Al-Rayyan et al., (2011) in the part of side effect of contraceptive method while this study is contraindicated to the present study as regards reasons of discontinuation .

Also this finding is disagreed with a study was carried out in Vietnamese by Nguyen et al., (2011) who found that the main reason for IUD removal, was excessive menstrual bleeding as a problem, infection. However, in disagreement with these findings Al-Rayyan et al., (2011) reported that one 
third of pills users group stopped the Combined Oral Contraceptive due to desire for pregnancy.

Merits of the study:

- The sample size was large. The large sample represents many places in the west sector of Assiut city. This sector includes: Kolta MCH, Hay Gharb $\mathrm{MCH}$, Elarbaeen $\mathrm{MCH}$ and Assiut General Hospital from different area according to map and flow, so it explores different socio- demographic classes.

- The participating women in the study were cooperative and the nurses help the researcher in collecting data and, facilitating follow up stage.

Limitation of the study:

- There was a contact barrier in follow up stage because the most of the women gave the researcher a wrong mobile number.

- The implant was not available in the family planning clinics during time of data collection, so the researcher can't assess the side effects of implant on menstruation.

\section{Conclusions:}

Contraceptive use significantly affect the menstrual cycle of its users as the main side effects encountered during contraceptive use and affects also their discontinuation rate with other causes.

\section{Recommendations}

- Contraceptive counseling must be included health information about menstrual disorders.

- More researches should be done to assess the impact of family planning counseling on reducing the rate of unwanted pregnancy.

\section{Acknowledgment}

Many thanks for every one help us to make this research (Administrative and Nursing staff). Also, special thanks for the clients who participated in this study

\section{References}

1. Abd el-latief A., Ahmed E., Moustafa M., \& Abd el hafez H., (2013): Relationship between using hormonal contraceptives, intrauterine device and secondary infertility, Med. J. Cairo

2. Adeyemi S., \& Adekanle D., (2012): Progestogen-only injectable contraceptive: Experience of women in Osogbo, southwesternNigeria, Annals of African Medicine, Volume : 11 Issue:1 Page:27-31

3. AL-Rayyan E., Bunimeri Z., Naser M., Dogom W., Khreisat B., (2011): Discontinuation rates among women using either the combined oral contraception: Acomparative study Journal Of The Royal Medical Services Vol. 18 No. 3 PP.29-31.

4. Azar F., \& Zanghi A., ( 2006): Assessment of Reasons for Discontinuation of Different Methods of Contraception. Journal of Medical Sciences, 6: 823-827 studies was performed in Tabriz.

5. Balogun O., Raji H., (2009): Clinical experience with injectable progestogen- only contraceptives at University of Ilorin Teaching Hospital: a five year review. Niger. Postgrad. Med .J. 16(4):260-263.

6. Ceylan, A., Ertem, M., Saka, G., \& Akdenz, N., (2009): ostabortion family planning counselingas a tool to increase contraceptive use. BMCPublic Health, 9:20

7. El-Zanaty F., \& Way A., (2008): Egypt Demographic and Health Survey Cairo, Egypt: Ministry of Health, El-Zanaty and Associates, and Macro International,Chapter 6pp.77-86.

8. EL-Zanaty F., (2014A): International Conference for Development and the Environment in the Arab World, environment geographic information systems and health information system (HIS) PP.1-3, 12-14.

9. Etemad A., El- shereef E., Gamal H., Abo Bakr A., \& Ahmed M., (2011): Contraceptive use dynamics and effect of counseling on usecontinuation of contraception in Assiut Governorate, Upper Egypt, Journal of American Science, 2011;7(6).

10. Family PLanning World Wide, Data Sheet, (2008): Family Planning HigHlig HtsLIGHTS, Population Reference Bureau.

11. Ghosh S., (2014): Prospective Observational Study Of The Pattern Of Usage Of Oral Contraceptive Pills In Partial Fulfillment Of The Doctor Of Master Of Pharmacy Ate Faculty Of Engineering And Technology

12. Jick S., Hernandez R., (2011): Risk of non-fatal venous thromboembolism in women using oral contraceptives containing drospirenone compared with women using oral contraceptives containing levonorgestrel: case-control study using United States claims data. BMJ. Apr 21 2011; 342:d2151.

13. JoAnn V., (2012): Introduction to Menstrual Abnormalities,Merck Manuals Professional Edition ,Pp.1.

14. Johnson T., Fahey J., (2012): Black cohosh: Coming full circle? J Ethnopharmacol. 2012;141(3):775-9.

15. Kamalifard M., Jamileh M., Zakaria M., \& Velayati A., (2014): Continuation and Discontinuation Reasons of LD Contraceptives among Iranian Women, International Journal of 
Women's Health and Reproduction Sciences,Vol. 2, No. 5, Autumn 2014, 287-290 ISSN 2330- 4456

16. Kumar M., Meena J., Sharma S., Poddar A., Dhalliwal V., Modi S., (2011): Contraceptive use among low-income urban married women in India. J Sex; 8(2):376-82 .

17. Lwelamira J., Mnyamagola G., \& Msaki M., (2012): Knowledge, Attitude and Practice (KAP) Towards Modern Contraceptives Among Married Women of Reproductive Age in Mpwapwa District, Central Tanzania, Journal of Social Sciences 4(3.,ISSN: 2041-3246 pp.235245.

18. Mahmoud, G., \& Byomy S., (2013):Fertility A Awareness And Family Planning Use Among Post Abortion Women In Egypt, life science journal 2013,10(1.(

19. Mansour D., Korver T., Petrova M., \& Fraser I., (2008): Marintcheva-Petrova $M$ et al. The effects of Implanon on menstrual bleeding patterns. Eur J Contra \& Reprod Health; 13(S1):13-18.

20. Naser O., Malas M., Ehab S., Al -Rayyan M., Ahmed S., \& Ghoweri M., (2009): Why Do Depo-Provera Users Discontinuatue? Journal of the Royal Medical Services Vol.16 No.3.

21. Nguyen T., Park M., Le M., \& Ngo, T., (2011): The dynamics of intrauterine device (IUD) use among Vietnamese women. Marie Stopes International

22. NHS National Institute for Clinical Excellence, (2010): Long acting reversible contraception.Available at www.nice. org.uk/ CG030

23. Ojule J., Oriji V., Okongwu C., (2010): A five year review of the complications of progestogen only injectable contraceptive at the University of Port-Harcourt Teaching Hospital. Niger J Med2010; 19:87-95 .

24. Pushpa B., Sangita N., Shivani A., \& Chitra T., (2011): Implanon Subdermal Single Rod Contraceptive Implant ,Journal Of Obstetrics And Gynecology Of India,61(4):422-425.

25. Roach L., (20 13): Uterine Bleeding: ACOG Updates Guidelines. Medscape Medical News. Available at http://www. medscape. com/viewarticle/806735

26. Roud L., Abdulmonem A., ashFord L., \& El-adadwy M., (2012): Women's need for family Planning in arab Countries , Arab States Regional Office

27. Sarkar, N., (2008): Barriers to emergency contraception (EC): Does prompting EC increase risk for contracting sexually transmitted diseases.
International Journal of Clinical Practice, 62: 1769-1775.

28. Stacey D., (2012): Implanon - The Contraceptive Implant.com Health's Disease and Condition content is reviewed by the Medical Review Board.

29. Stacey D., (2014): Contraceptive Injections, OBG Management, Vol. 17, No 8.

30. Subir J.,(2010): Pattern of Contraception use among Women attending Family Planning Centers in Erbil City Zanco J.Med Sci., Vol.14,No. (2), pp.43-45

31. Thapa S., (2012): Early discontinuation of intrauterine device in Nepal a retrospective study, Journal of Public Health ;1(3):309-319

32. Tocce K., Sheeder J., Teal S., (2012): Rapid repeat pregnancy in adolescents: do immediate postpartum contraceptive implants make a difference? Am J Obstet Gynecol ; 206:481.e1.

33. Trussell J., Raymond E., (2011): Emergency Contraception: A Last Chance to Prevent Unintended Pregnancy.Available at http://ec.princeton.edu/questions/ec-review.

34. USAID, (2007): Reducing Discontinuation of Contraceptive Use and Unmet Need for Family Planning:PolicyOptions downloadedathttp://www.healthpolicyinitiative.c om. World Health Organisation,(2007): Family Planning: A global handbook for providers , Available from URL: http:// www. who.int/ entity/ reproductivehealth/ publications/ family_planning. NHS National Institute for Clinical Excellence, (2010): Long acting reversible contraception.Available at www.nice. org.uk/ CG030

35. Veisi F., Progesterone Acetate (DMPA) An., \& Zangeneh M., (2013): Comparison of Two Different Injectable Contraceptive Methods: Depo-medroxy d Cyclofem, J Family Reprod Health. 2013 Sep; 7(3): 109-113. PMCID: PMC4064779.

36. WHO,(2011 D):Family Planning A GLOBAL HANDBOOK FOR PROVIDERS ,United States, Baltimore and Geneva, CHAPTER9 Copper-Bearing Intrauterine Device,PP.131-133.

37. Winner B., Peipert, J., Zhao Q., Buckel C., Madden T., (2009): World Contraceptive Use, Available at: ww.un.org/ esa/ population/publications/WCU2009/Main.html. Accessed July 20, 2010.

38. World Health Organisation, (2007): Family Planning: A global handbook for providers , Available from URL: http:// www. who.int/ entity/ reproductivehealth/ publications/ family_planning. 